\title{
PERBEDAAN KEMAMPUAN PEMECAHAN MASALAH MATEMATIS SISWA MELALUI PEMBELAJARAN KOOPERATIF TIPE TEAM-ASSISTED INDIVIDUALIZATION DAN NUMBERED HEAD TOGETHER
}

\author{
Septya Giartianti ${ }^{1}$, E.Elvis Napitupulu ${ }^{2}$ \\ ${ }^{1,2)}$ FMIPA Universitas Negeri Medan \\ Septya095@gmail.com
}

\begin{abstract}
ABSTRAK
Penelitian ini bertujuan untuk melihat apakah ada perbedaan kemampuan pemecahan masalah matematik siswa menggunakan pembelajaran kooperatif tipe TAI dan NHT pada kelas VII SMP Negeri 3 Pulau Rakyat. Jenis penelitian ini adalah eksperimen semu. Populasi dalam penelitian ini adalah seluruh siswa kelas VII Semester 2 SMP Negeri 3 Pulau Rakyat yang terdiri dari 5 kelas dengan jumlah keseluruhan siswa 160 orang dan sampel penelitian ini adalah siswa kelas VII-1 dan siswa kelas VII-3 sebanyak 64 orang. Data yang diperlukan diperoleh dengan menggunakan tes kemampuan pemecahan masalah matematika siswa berupa uraian sebanyak 4 soal. Dari hasil analisis data diperoleh rata-rata hasil tes kemampuan pemecahan masalah matematik siswa melalui pembelajaran kooperatif tipe TAI adalah 27,28 dengan simpangan baku 2,65 dan rata-rata hasil tes kemampaun pemecahan masalah matematik siswa melalaui pembelajaran kooperatif tipe NHT adalah 22,25 dengan simpangan baku 3,23. Untuk uji hipotesis digunakan uji $\mathrm{t}$, dari hasil perhitungan diperoleh $\mathrm{t}_{\text {hitung }}=6,80$ dengan kriteria pengujian tolak $\mathrm{H}_{\mathrm{o}}$ dan terima $\mathrm{H}_{\mathrm{a}}$ jika $\mathrm{t}_{\text {hitung }} \geq 1,6697$ sehingga terlihat bahwa ternyata $\mathrm{t}_{\text {hitung }}$ tidak berada pada daerah penerimaan $\mathrm{H}_{\mathrm{O}}$ yang berarti $\mathrm{H}_{\mathrm{o}}$ ditolak dan $\mathrm{H}_{\mathrm{a}}$ diterima atau dengan kata lain terdapat perbedaan kemampuan pemecahan masalah matematik siswa menggunakan model pembelajaran kooperatif tipe TAI dan NHT kelas VII SMP Negeri 3 Pulau Rakyat.
\end{abstract}

Kata Kunci : kemampuan pemecahan masalah matematika, TAI, NHT

\section{ABSTRACT}

This study aims to determine whether are differences in problem solving skills of mathematics students using cooperative learning type TAI and NHT in class VII SMP Negeri 3 Pulau Rakyat. This type of research is quasi experiment. The population in this study is all students of grade VII semester 2 SMP Negeri 3 Pulau Rakyat consisting of 5 classes with total 160 students and the sample of this study are VII-1 and VII-3 as many as 64 students. The required dara is obtained by using the students' math problem solving test in the form of a description of 4 question. From the results of data analysis obtained the average test results of students mathematics problem solving abilities through cooperative learning type TAI is 27,28 with varians 2,65 and the average test result of students' mathematics problem solving abilities through cooperative leraning type NHT is 22,25 with varians 3,28 . To test hypothesis used $t$ test, from the calculation results obtained $\mathrm{t}_{\text {count }}$ with the test reject $\mathrm{H}_{\mathrm{o}}$ and accept $\mathrm{H}_{\mathrm{a}}$ if $\mathrm{t}_{\text {count }} \geq 1,6697$ so it looks that $\mathrm{t}_{\text {count }}$ is not reside in the $\mathrm{H}_{\mathrm{o}}$ accetance area which means $\mathrm{H}_{\mathrm{o}}$ rejected and $\mathrm{H}_{\mathrm{a}}$ accepted or in other

Septya Giartianti, E.Elvis Napitupulu. Perbedaan Kemampuan Pemecahan Masalah Matematis Siswa Melalui Pembelajaran Kooperatif Tipe Team-Assisted Individualization dan Numbered Head Together. Jurnal Inspiratif, Vol. 4, No. 1 April 2018. 
words there are differences problem solving ability of mathematics students using cooperative learning type TAI and NHT in class VII SMP Negeri 3 Pulau Rakyat.

\section{Keywords: Mathematical Problem Solving Abilities, TAI, NHT}

\section{PENDAHULUAN \\ LATAR BELAKANG}

Pendidikan adalah sarana dan alat yang tepat dalam membentuk masyarakat dan bangsa yang dicitacitakan, yaitu masyarakat yang berbudaya dan cerdas.Matematika merupakan salah satu mata pelajaran di sekolah yang dapat di gunakan untuk mencapai tujuan tersebut.Hampir semua aktivitas manusia berhubungan dengan matematika. Selain itu, matematika termasuk salah satu bidang studi yang paling diutamakan saat proses belajar mengajar di sekolah. Hal ini dapat dilihat dari jam pelajaran yang harus di tempuh siswa di sekolah. Tidak hanya di sekolah, bahkan mayoritas para orang tua di rumah memberikan anaknya belajar matematika tambahan dengan cara mendaftarkan anaknya untuk mengikuti kursus Matematika.

Banyak alasan yang menjadikan mata pelajaran matematika perlu dipelajari oleh siswa. Abdurrahman (2102: 204) mengemukakan bahwa:

Matematika perlu diajarkan kepada siswa karena (1) selalu digunakan dalam segala kehidupan; (2) semua bidang studi memerlukan keterampilan yang sesuai; (3) merupakan sarana komunikasi yang kuat, singkat, dan jelas; (4) dapat digunakan untuk menyajikan informasi dalam berbagai cara; (5) meningkatkan kemampuan berpikir logis, ketelitian, dan kesadaran keruangan; dan (6) memberikan kepuasan terhadap usaha memecahkan masalah yang menantang.

Dari pernyataan diatas, salah satu alasan perlunya belajar matematika adalah untuk memecahkan masalah.Pemecahan masalah merupakan bagian dari kurikulum matematika yang sangat penting, karena dalam penyelesaianny siswa dimungkinkan memperoleh pengalaman menggunakan pengetahuan serta keterampilan yang sudah dimiliki untuk diterapkan pada pemecahan masalah.

Pentingnya kemampuan pemecahan masalah ini juga dikemukakan oleh Hudojo (2015:133) yang menyatakan bahwa "Pemecahan masalah merupakan suatu hal yang esensial dalam pembelajaran matematika disekolah, disebabkan antara lain: (1) Siswa menjadi terampil menyeleksi informasi yang relevan, kemudian menganalisanya dan kemudian meneliti hasilnya; (2) kepuasan intelektual akan timbul dari dalam, yang merupakan masalah instrinsik; (3) Potensi inteektual siswa meningkat; (4) Siswa belajar bagaimana melakukan penemuan dengan melalui proses melakukan penemuan".

Matematika adalah ilmu yang penting tetapi pada kenyataannya, pelajaran matematika kurang diminati, ditakuti, dan membosankan bagi siswa. Ini bisa dilihat dari kemampuan matematika siswa yang lemah. Salah satu kelemahan di kalangan siswa adalah kelemahan siswa dalam memecahkan masalah matematika. Dimana siswa mengeluh dan menemukan kesulitan dalam memecahkan masalah dalam matematika sehingga siswa terlihat kurang mampu memecahkan soal matematika (Novriani dan Surya, 2017)

Salah satu fokus pembelajaran matematika saat ini adalah meningkatkan kemampuan pemecahan masalah matematika siswa melalui pembelajaran yang berawal dari suatu pengalaman siswa yang terjadi dalam kehidupan sehari-hari. Dengan pembelajaran melalui pengalaman siswa yang terjadi dalam kehidupan sehari-hari maka akan membuat siswa lebih memahami dan mengigat konsep yang mereka pelajari. Rosli dkk (2013:54)

Septya Giartianti, E.Elvis Napitupulu. Perbedaan Kemampuan Pemecahan Masalah Matematis Siswa Melalui Pembelajaran Kooperatif Tipe Team-Assisted Individualization dan Numbered Head Together. Jurnal Inspiratif, Vol. 4, No. 1 April 2018. 
berpendapat bahwa "Pemecahan masalah dan telah menjadi kegiatan kognitif yang penting dalam proses belajar mengajar matematika".

Selain itu Sumiati dan Asra (2013:89) mengemukakan bahwa "Kemampuan pemecahan masalah banyak menunjang kreativitas seseorang, yaitu kemampuan menciptakan ide baru, baik yang bersifat asli ciptaanya sendiri, maupun merupakan suatu modifikasi (perubahan) dari berbagai ide yag telah ada sebelumnya".

Dengan demikian, kemampuan pemecahan masalah menjadi salah satu kegiatan yang penting untuk dilaksananakan dalam kegiatan belajarmengajar di sekolah. Yang menjadi masalah adalah bagaimana kemampuan pemecahan masalah itu dilaksanakan dengan efisien dalam kegiatan belajar mengajar matematika. Keterampilan memecahkan masalah harus dimiliki oleh siswa dan keterampilan ini akan dimiliki siswa apabila guru mengajarkan dan menstimulus kemampuan siswa untuk dapat menyelesaikan masalah dalam pembelajaran matematika.

Seorang siswa $\begin{array}{r}\text { dikatakan } \\ \text { pemecahan }\end{array}$
memliki $\begin{gathered}\text { kemampuan } \\ \text { dalam pembelajaran }\end{gathered}$
masalah
matematika ketika siswa mencapai
criteria-kriteria tertentu atau biasa
dikenal dengan indikator. Menurut polya
(dalam Surya dan Rahayu, 2014),
terdapat empat tahap utama dalam
proses pemecahan masalah matematika,
yaitu: 1) memahami masalah
(understanding the problem), 2)
menentukan rencana strategi pemecahan
masalah (devising a plan), 3)
melaksanakan rencana pemecahan
masalah (carryingout the plan), 4)
memeriksa kembali jawaban yang
diperoleh (looking back). Namun dalam
penelitian ini terdapat tiga indicator
pemecahan masalah yang digunakan,

yakni : 1) memahami masalah, 2) memilih strategi/cara penyelesaian masalah yang tepat, 3) menerapkan strategi dan menyelesaikan masalah.

Dalam setiap permasalahan memahami masalah diukur melalui menuliskan unsur-unsur yang diketahui dan ditanya dari soal, memilih strategi/cara penyelesaian masalah untuk menyelesaikan masalah matematika diukur melalui menuliskan rumus dan metode yang dapat digunakan dalam menyelesaikan/memecahkan masalah, dan menerapkan strategi dan menyelesaikan masalah diukur melalui pelaksanaan rencana pemecahan sesuai dengan rumus atau metode yang dipilih dengan benar.

Permasalahan yang sedang di hadapi saat ini yaitu kemampuan pemecahan masalah yang dimiliki siswa terhadap matematika masih rendah.Hal ini dapat dilihat dari hasil tes yang dilakukan peneliti di kelas VII di SMP Negeri 3 Pulau Rakyat menunjukkan bahwa kemampuan pemecahan masalah siswa masih rendah dalam menyelesaikan soal sebagai berikut.

Sebanyak 24 siswa tereliminasi dalam babak penyisihan pada pemilihan siswa berprestasi.Babak penyisihan ini menyisakan 96 siswa untuk babak berikutnya.

a. Tuliskan apa yang diketahui dan apa yang ditanyakan dari soal tersebut secara lengkap!

b. Bagaimana cara untuk mengetahui persamaan dari soal tersebut?

c. Tulislah persamaan linier dari soal tersebut!

Septya Giartianti, E.Elvis Napitupulu. Perbedaan Kemampuan Pemecahan Masalah Matematis Siswa Melalui Pembelajaran Kooperatif Tipe Team-Assisted Individualization dan Numbered Head Together. Jurnal Inspiratif, Vol. 4, No. 1 April 2018. 
Tabel 1. Analisis Pekerjaan Siswa

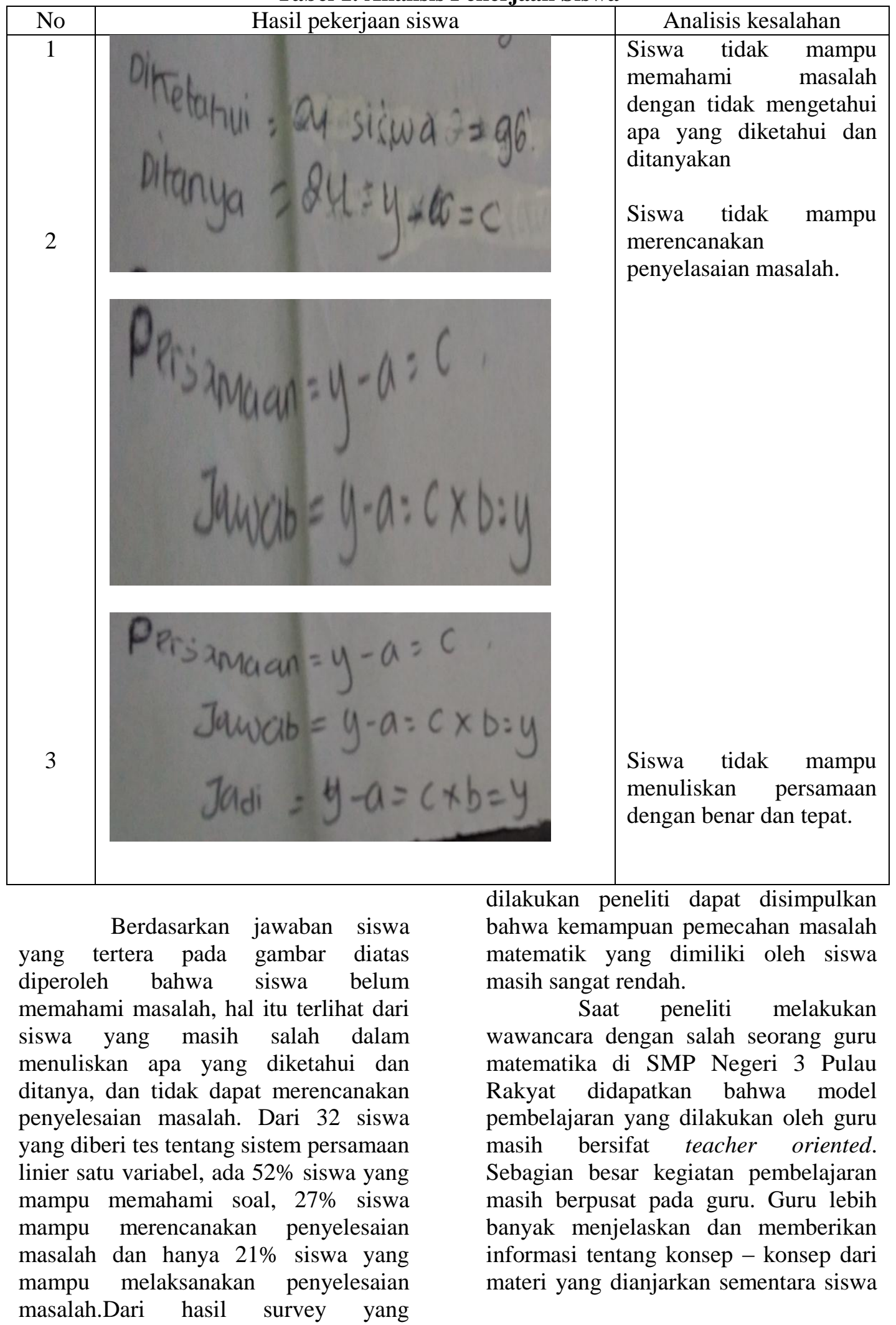

Septya Giartianti, E.Elvis Napitupulu. Perbedaan Kemampuan Pemecahan Masalah Matematis Siswa Melalui Pembelajaran Kooperatif Tipe Team-Assisted Individualization dan Numbered Head Together. Jurnal Inspiratif, Vol. 4, No. 1 April 2018. 
hanya mendengarkan dan membahas soal - soal dari guru.

Selain itu juga pembelajaran yang digunakan oleh guru belum mampu mengembangkan kemampuan pemecahan masalah matematika yang dimiliki siswa.Oleh karena itu, pemilihan strategi merupakan hal yang sangat menentukan hasil belajar dan kemampuan siswa.

Guru harus mampu mencari strategi pembelajaran yang sesuai sehingga dapat mengembangkan kemampuan pemecahan masalah matematika siswa. Karena diasumsikan dengan adanya strategi yang sesuai, efektif dan efisien terhadap pembelajaran akan menghasilkan hasil yang baik pula. Salah satu model pembelajaran yang dapat digunakan adalah model pembelajaran kooperatif.Dengan model pembeljaran kooperatif, maka diharapkan dapat mengatasi kesulitan siswa dalam mempelajari matematika dan siswa dapat menemukan penyelesaianpenyelesaian masalah dari soal-soal pemecahan masalah. Sehingga siswa akan termotivasi untuk belajar matematika dan mampu mengembangkan ide dan gagasan mereka dalam menyelesaikan masalah matematika.

Slavin (2005:4) menyatakan

bahwa :"Pembelajaran kooperatif merujuk pada berbagai macam metode pengajaran dimana para siswa bekerja dalam kelompok - kelompok kecil untuk saling membantu satu sama lainnya dalam mempelajari materi pembelajaran".

Dalam hal ini penulis memilih dua tipe pembelajaran yaitu pembelajaran kooperatif tipe TeamAssisted Individualization (TAI) dan Number Head Together ( NHT ).

Pembelajaran kooperatif tipe TAI (Team Assisted Individualization) merupakan salah satu tipe dari model pembelajaran kooperatif dimana siswa ditempatkan dalam kelompokkelompok kecil (4 sampai 5 siswa) yang heterogen dan selanjutnya diikuti dengan pemberian bantuan secara individu bagi siswa yang memerlukannya. Slavin (2005:189) menyatakan bahwa: "Matematika TAI diprakasai sebagai usaha merancang sebuah bentuk pengajaran individual yang bisa menyelesaikan masalahmasalah yang membuat metode pengajaran individual menjadi tidak efektif".

Farnika (2015) menyatakan bahwa: "Melalui model pembelajaran kooperatif tipe TAI dapat meningkatkan kemampuan pemecahan masalah matematik siswa karena pembelajaran kooperatif tipe TAI dikembangkan untuk memecahkan masalah pembelajaran klasikal diantaranya masalah tingkat pemahaman siswa atas materi yang disampaikan oleh guru dan masalah keakuratan dan kecepatan siswa dalam belajar".

NHT (Number Head Together) merupakan salah satu model pembelajaran kooperatif yang dikembangkan oleh Spencer Kagan pada tahun 1993. Teknik ini memberikan kesempatan kepada siswa untuk saling membagikan ide - ide dan mempertimbangkan jawaban yang paling tepat. Selain itu, tekhnik ini juga mendorong siswa untuk meningkatkan kerjasama mereka. Tehnik ini bisa digunakan untuk semua mata pelajaran dan semua tingkatan usia anak didik.

Model pembelejaran kooperatif dilandasi oleh teori konstruktivisme. Teori konstruktivisme menyatakan bahwa siswa harus menemukan sendiri dan mentransformasikan informasi kompleks, mengecek informasi baru dengan aturan-aturan lama dan merevisinya apabila aturan-aturan itu tidak lagi sesuai. Bagi siswa agar benarbenar memahami dan menerapkan pengetahuan, mereka harus bekerja memecahkan masalah dan menemukan segala sesuatu untuk dirinya.

Menuru teori konstruktivisme, satu prinsip yang paling penting dalam

Septya Giartianti, E.Elvis Napitupulu. Perbedaan Kemampuan Pemecahan Masalah Matematis Siswa Melalui Pembelajaran Kooperatif Tipe Team-Assisted Individualization dan Numbered Head Together. Jurnal Inspiratif, Vol. 4, No. 1 April 2018. 
psikologi pendidikan adalah bahwa guru tidak hanya sekedar memberikan pengetahuan kepada siswa. Siswa harus membangun sendiri pengetahuan di dalam benaknya. Guru dapat memberikan kemudahan dengan memberikan kesempatan siswa untuk menemukan atau menerepkan ide-ide mereka sendiri dan menagjar siswa menjadi sadar dan secara sadar menggunakan strategi mereka sendiri dalam belajar.

Pembelajaran kooperatif disusun dalam sebuah usaha untuk meningkatkan partisipasi siswa, memfasilitasi siswa dengan pengalaman sikap kepemimpinan dan membuat keputusan dalam kelompok, serta memberikan kesempatan pada siswa untuk berinteraksi dan belajar bersamasama siswa yang berbeda latar belakangnya.

Sejalan dengan itu, Rusman (2012:202) mengemukakan bahwa "Pandangan kontruktivisme Piaget dan Vygotsky dapat berjalan berdampingan dalam proses belajar, kontruktivisme Piaget yang menekankan pada kegiatan internal individu terhadap objek yangdihadapi dan pengalaman yang dimiliki orang tersebut.Sedangkan konstruktivisme Vygotsky menekankan pada interaksi sosial dan melakukan konstruksi pengetahuan dari lingkungan sosialnya".

Dari uraian diatas dapat dirumuskan bahwa pembelajaran kooperatif tipe NHT dan tipe TAI sesuai dengan falsafah konstruktivisme yaitu pengajaran dan pembelajaran yang berpusat pada siswa dimana siswa berinteraksi secara aktif dalam kelompok dengan pertukaran ide dan pemeriksaan ide sendiri serta guru berpean sebagai fasilitator yang membantu siswa membina pengetahuan dan menyelesaikan masalah.

Berkaitan dengan pembelajaran matematika, pelajaran matematika yang beracuan pada pembelajaran yang melibatkan siswa aktif belajar memahami dan mampu memecahkan masalah matematika berdasarkan pengalaman sendiri.Melalui model pembelajaran kooperatif tipe TAI dan NHT maka diharapkan dapat mengatasi kesulitan siswa dalam mempelajari matematika khususnya pada materi aritmatika sosial serta siswa dapat secara aktif menemukan sendiri permasalahan dari suatu materi. Sehingga siswa akan termotivasi untuk belajar matematika dan mampu mengembangkan ide-ide atau gagasan mereka dalam memecahkan masalah.

\section{METODE PENELITIAN}

Populasi dalam penelitian ini adalah seluruh siswa kelas VII SMP Negeri 3 Pulau Rakyat Tahun Ajaran 2017/2018 yang terdiri dari 5 kelas yang masing-masing kelas berjumlah 32 siswa. Pengambilan sampel dalam penelitian ini dilakukan dengan menggunakan teknik random sampling yaitu pengambilan sampel dengan proses pengacakan. Pengambilan sampel dilakukan seperti mengambil undian. Pengambilan undian pertama ditentukan sebagai kelas eksperimen A sedangkan pengambilan undian kedua ditentukan sebagai kelas eksperimen $\mathrm{B}$, sehingga diperoleh kelas VII-3 sebanyak 32 siswa sebagai kelas eksperimen A kelas VII-1 sebanyak 32 siswa sebagai kelas eksperimen B.

Jenis penelitian ini adalah penelitian eksperimen semu (quasi experiment). Penelitian ini melibatkan dua kelas yaitu eksperimen A dan kelas eksperimen B yang diberi perlakuan berbeda. Pada kelas eksperimen A diberikan pengajaran materi persamaan dan pertidaksamaan linier satu variabel dengan menggunakan model kooperatif tipe TAI sedangkan pada eksperimen B diberi perlakuan pengajaran materi persamaan dan pertidaksamaan linier satu variabeldengan menggunakan model tipe NHT. Untuk mengetahui kemampuan pemecahan masalah matematik yang diperoleh dari

Septya Giartianti, E.Elvis Napitupulu. Perbedaan Kemampuan Pemecahan Masalah Matematis Siswa Melalui Pembelajaran Kooperatif Tipe Team-Assisted Individualization dan Numbered Head Together. Jurnal Inspiratif, Vol. 4, No. 1 April 2018. 
penerapan perlakuan tersebut, maka siswa diberikan tes. Adapun bentuk desain yang digunakan adalah Postest Only Control Group Design. Berikut ini rancangan penelitian yang akan dilakukan (menurut Arikunto, 2009:212), yaitu:

Tabel 2. Rancangan Penelitian

\begin{tabular}{|c|c|c|}
\hline Kelas & Perlakuan & Tes Akhir \\
\hline Eksperimen A & $\mathrm{X}_{1}$ & $\mathrm{O}$ \\
\hline Eksperimen B & $\mathrm{X}_{2}$ & $\mathrm{O}$ \\
\hline
\end{tabular}

$\mathrm{O}$ : Postes

$\mathrm{X}_{1}$ : Pembelajaran menggunakan model kooperatif tipe TAI

$\mathrm{X}_{2}$ : Pembelajaran menggunakan model kooperatif tipe NHT

Alat pengumpulan data yang digunakan adalah tes. Tujuan tes ini adalah untuk mengetahui apakah ada pengaruh adanya perlakuan (skor rata rata postest kelas eksperimen A dibanding dengan skor rata-rata postest kelas eksperimen B) terkait materi aritmatika sosial pada semester genap.
Sebelum dilakukan uji-t, dilakukan uji normalitas dan homogenitas data.

\section{HASIL PENELITIAN}

Dari hasil postes diperoleh rata-rata posttest kelas eksperimen A dengan pembelajaran kooperatif tipe TAI adalah 27,28 . Sedangkan, rata-rata posttest kelas eksperimen B dengan pembelajaran kooperatif tipe NHT adalah 22,25. Secara ringkas hasil posttest kedua kelas diperlihatkan pada Tabel 3. berikut.

\section{Tabel 3. Data Hasil Tes Siswa Kelas eksperimen A dan B}

\begin{tabular}{|l|l|l|l|}
\hline No & Statistik Deskriptif & Eksperimen A & Eksperimen B \\
\hline 1. & Jumlah Siswa & 32 & 32 \\
\hline 2. & Jumlah Nilai & 873 & 712 \\
\hline 3. & Rata-rata & 27,28 & 22,25 \\
\hline 4. & Simpangan Baku & 2,65 & 3,23 \\
\hline 5. & Varians & 7,05 & 10,45 \\
\hline 6. & Nilai Maksimum & 32 & 29 \\
\hline 7. & Nilai Minimum & 21 & 17 \\
\hline
\end{tabular}

Salah satu persyaratan analisis yang harus dipenuhi sebelum melakukan uji statistik parametrik adalah sebaran data kedua sampel harus berdistribusi normal. Untuk mengetahui sebaran data berdistribusi normal atau tidak dapat dilakukan uji normalitas dengan meggunakan uji Liliefors dengan syarat normal yang harus dipenuhi adalah $\mathrm{L}_{\text {hitung }}<\mathrm{L}_{\text {tabel }}$ pada taraf $\alpha=0,05$. Secara ringkas hasil uji normalitas data postes kedua kelas diperlihatkan pada Tabel 4. berikut.

Tabel 4. Ringkasan Hasil Pengujian Normalitas Data

\begin{tabular}{|l|c|l|l|l|l|}
\hline No & Data & \multicolumn{1}{|c|}{ Kelas } & \multicolumn{1}{|c|}{$\mathbf{L}_{\text {hitung }}$} & \multicolumn{1}{c|}{$\mathbf{L}_{\text {tabel }}$} & \multicolumn{1}{|c|}{ Kesimpulan } \\
\hline 1. & Postest & Eksperimen A & 0,1531 & 0,1566 & Berdistribusi normal \\
\hline 2. & Postest & Eksperimen B & 0,1017 & 0,1566 & Berdistribusi normal \\
\hline
\end{tabular}

Dari tabel di atas, terlihat bahwa data postes dari kedua kelas sampel yaitu kelas siswa yang belajar

dengan model pembelajaran kooperatif tipe TAIdan NHT memiliki sebaran data yang berdistribusi normal pada taraf

Septya Giartianti, E.Elvis Napitupulu. Perbedaan Kemampuan Pemecahan Masalah Matematis Siswa Melalui Pembelajaran Kooperatif Tipe Team-Assisted Individualization dan Numbered Head Together. Jurnal Inspiratif, Vol. 4, No. 1 April 2018. 
signifikansi $\alpha=0,05$ dimana $\mathrm{L}_{\text {hitung }}<$ $\mathrm{L}_{\text {tabel. }}$

Pengujian homogenitas data diuji menggunakan uji $\mathrm{F}$ yang bertujuan untuk mengetahui kehomogenan varians data-data kelompok sampel penelitian. Data masing-masing kelompok sampel dinyatakan memiliki varians yang homogen, apabila nilai $\mathrm{F}_{\text {hitung }}<\mathrm{F}_{\text {tabel }}$ pada taraf $\alpha=0,05$. Secara ringkas hasil perhitungan uji homogenitas data kedua kelas diperlihatkan pada Tabel 5 . berikut.

Tabel 5. Ringkasan Hasil Pengujian Homogenitas Data

\begin{tabular}{|l|c|l|l|l|l|}
\hline Data & Varians Terbesar & Varians Terkecil & $\mathbf{F}_{\text {hitung }}$ & $\mathbf{F}_{\text {tabel }}$ & Kesimpulan \\
\hline Postes & 10,45 & 7,05 & 1,48 & 1,83 & Homogen \\
\hline
\end{tabular}

Tabel diatas menggambarkan tentang pengujian homogenitas data kemampuan pemecahan masalah matematik kelas eksperimen 1 dan eksperimen II. Karena kedua kelas memiliki varians yang berbeda, sehingga dapat ditentukan mana varians terbesaar dan varians terkecil. Varians-varians tersebut dapat digunakan untuk mencari harga $\mathrm{F}_{\text {hitung }}$, dan untuk $F_{\text {tabel }}$ dapat dicari dengan menggunakan interpolasi. Sehingga, dari tabel diatas dapat dilihat bahwa $\mathrm{F}_{\text {hitung }}<$ $F_{\text {tabel }}$ maka disimpulkan bahwa sampel postest berasal dari data yang homogen.

Setelah diketahui kedua kelompok data kemampuan pemecahan masalah matematik siswa adalah berdistribusi normal dan mempunyai varians yang homogen, selanjutnya dilakukan uji hipotesis dengan menggunakan uji $\mathrm{t}$, hal ini dilakukan untuk mengetahui apakah hipotesis penelitian diterima atau ditolak.

Pengujian hipotesis yang dilakukan pada data postes, diuji statistik dua pihak dengan cara membandingkan rata-rata postes antara kelas eksperimen 1 dan kelas eksperimen 2.

Secara ringkas hasil perhitungan uji hipotesis dapat dilihat dalam tebel berikut.

Tabel 6. Ringkasan Hasil Pengujian Hipotesis Penelitian

\begin{tabular}{|c|c|c|c|c|}
\hline \multicolumn{2}{|c|}{$\bar{X}$} & \multirow{2}{*}{$\mathbf{t}_{\text {hitung }}$} & \multirow{2}{*}{$\mathbf{t}_{\text {tabel }}$} & \multirow{2}{*}{ Kesimpulan } \\
\hline Kelas eksperimen A & Kelas eksperimen B & & \\
\hline 27,28 & 22,25 & 6,80 & 1,6697 & Tolak Ho \\
\hline
\end{tabular}

Dari data postest di atas diperoleh $\mathrm{t}_{\text {hitung }}$ $=6,80$ dan $\mathrm{t}_{\text {tabel }}=1,6697$ dengan $\alpha=$ 0,05 dan $\mathrm{dk}=62$, diperoleh bahwa untuk kriteria pengujian terima $H_{0}$ jika $1.6697<t_{\text {hitung }}<1,6697$ untuk harga $\mathrm{t}$ lainnya $H_{0}$ ditolak, $\mathrm{t}_{\text {hitung }}=6,80$ tidak berada pada daerah penerimaan $H_{0}$ maka $H_{0}$ ditolak, $H_{a}$ diterima yang berarti terdapat perbedaan kemampuan pemecahan masalah matematik siswa melalui pembelajaran kooperatif tipe Team Assysted Individualization dengan pembelajaran kooperatif tipe Numbered
Head Together Kelas VII SMP Negeri 3 Pulau Rakyat.

\section{PEMBAHASAN}

Penelitian yang dilakukan di SMP Negeri 3 Pulau Rakyat ini menggunakan dua model pembelajaran yang berbeda yaitu kooperatif tipe Team Assysted Individualization (TAI) dan kooperatif tipe Numbered Head Together (NHT). Pembelajaran kooperatif tipe TAI diterapkan di kelas VII-3 (Eksperimen A) yang terdiri dari 32 siswa dan pembelajaran kooperatif tipe NHT diterapkandi kelas VII-1 (Eksperimen B) yang terdiri dari 32 siswa.

Septya Giartianti, E.Elvis Napitupulu. Perbedaan Kemampuan Pemecahan Masalah Matematis Siswa Melalui Pembelajaran Kooperatif Tipe Team-Assisted Individualization dan Numbered Head Together. Jurnal Inspiratif, Vol. 4, No. 1 April 2018. 
Kedua kelas sampel diberikan perlakukan yang berbeda. Setelah diberi perlakuan yang berbeda pada kelas Eksperimen A dan kelas Eksperimen B, kemudian kedua kelas diberikan postes atau tes akhir untuk mengetahui kemampuan pemecahan masalah matematik siswa kelas eksperimen A dan kelas eksperimen B. Postest terdiri dari empat butir soal yang mengandung aspek atau indikator pemecahan masalah, yaitu dimulai dari memahami masalah, membuat rencana penyelesaian, dan melaksanakan rencana penyelesaian. Dari hasil penelitian diperoleh rata-rata postest kelas eksperimen A adalah 27,28 dan nilai rata-rata postest kelas ekpserimen $\mathrm{B}$ adalah 22,25. Berdasarkan nilai rata-rata postest tersebut sudah nampak perbedaan kemampuan pemecahan masalah kedua kelas sampel.

Secara keseluruhan dari hasil postest yang ada diperoleh bahwa terdapat perbedaan kemampuan pemecahan masalah matematik siswa melalui pembelajaran kooperatif pada kelas eksperimen A yakni dengan model kooperatif tipe Team Assysted Individualization dengan kelas eksperimen B yakni dengan model kooperatif tipe Numbered Head Together Kelas VII SMP Negeri 3 Pulau Rakyat.

Selama proses pembelajaran di kedua kelas pun, peneliti memperlihatkan bagaimana karakteristik siswa ketika berdiskusi secara berkelompok dalam kelas Eksperimen A beranggotakan 4 orang dalam satu kelompok dan begitu juga pada kelas Eksperimen B berdiskusi secara kelompok dan setiap anggota kelompok mendapat penomoran di kepala masingmasing. Kelompok disusun berdasarkan kemampuan yang berbeda-beda (heterogen).

Slavin (2005:189) menyatakan bahwa pada pembelajaran TAI membuat para siswa bekerja dalam tim-tim pembelajaran kooperatif dan mengemban tanggung jawab mengelola dan memeriksa secara rutin, saling membantu satu sama lain dalam menghadapi masalah, dan saling memberi dorongan untuk maju. Hal ini membuat siswa aktif dalam berdiskusi. Peneliti melihat kelas ini memiliki kerjasama dan rasa tanggung jawab yang sangat baik. Karena didalam setiap kelompok ada anggota kelompok lain yang dapat melakukan pengecekan atas jawaban temannya,hal ini membuat komunikasi antar anggota kelompok terjalin dengan baik. Penilaian kelompok secara individu juga membuat anggota kelompok semakin bersemangat agar kelompoknya tidak berada di urutan terbawah dan saling membantu sesama anggota kelompok dalam menyelesaikan masalah.

Lain hal yang terjadi pada kelas eksperimen $\mathrm{B}$ dengan model pembelajaran NHT. Kelas tersebut tidak terlalu aktif karena masih banyaknya siswa yang hanya diam. Menurut Istarani (2012: 13) kekurangan dari model NHT yakni siswa yang pendiam akan merasa sulit untuk berdiskusi didalam kelompok dan susah dimintai pertanggungjawabnnya. Dalam diskusi terkadang terjadi perdebatan yang kurang bermanfat yang tidak sesuai dengan permasalahan yang ada dalam Lembar Aktivitas Siswa. Pada kelas Numbered Head Together terjadi pelemparan pertanyaan-pertanyaan kepada siswa dengan sistem menjawab berdasarkan nomor yang disebut guru dan menunjuk secara acak siswa, yang berakibatkan ada siswa yang tidak bisa menjawab dan kurang jelas menjelaskan karena pada saat diskusi yang beranggotakan 4 orang dalam kelompok, hanya 1-2 orang saja yang bekerja dan yang lainnya hanya menunggu jawaban dari teman satu kelompoknya.

Dilihat dari sisi tingkat kemampuan pemecahan masalah matematik siswa, kedua kelas juga memiliki perbedaan signifikan. Tingkat kemampuan pemecahan masalah matematik siswa melalui pembelajaran TAI terdiri dari 13 siswa dengan

Septya Giartianti, E.Elvis Napitupulu. Perbedaan Kemampuan Pemecahan Masalah Matematis Siswa Melalui Pembelajaran Kooperatif Tipe Team-Assisted Individualization dan Numbered Head Together. Jurnal Inspiratif, Vol. 4, No. 1 April 2018. 
kategori sangat tinggi, 11 siswa dengan kategori tinggi, 8 siswa dengan kategori sedang, tidak ada siswa dengan kategori rendah dan sangat rendah. Sedangkan tingkat kemampuan pemecahan masalah matematik siswa melalui pembelajaran NHT terdiri dari 2 siswa dengan kategori sangat tinggi, 3 siswa dengan kategori tinggi, 16 siswa dengan kategori sedang, 9 siswa dengan kategori rendah, 2 siswa dengan kategori sangat rendah.

Berdasarkan fakta diatas siswa yang belajar dengan model kooperatif tipe TAI memiliki tingkat kemampuan pemecahan masalah yang lebih baik dibandingkan dengan siswa yang belajar dengan model kooperatif tipe NHT. Hal itu bisa dilihat dari lebih banyaknya siswa yang tingkat kemampuan pemecahan masalah matematiknya berkategori sangat tinggi pada kelas TAI yakni 13 siswa dibandingkan dengan kelas NHT yang banyaknya siswa dengan tingkat kemampuan pemecahan masalah matematik berkategori sangat tinggi lebih sedikit yakni hanya 2 orang siswa.

Adapun kekurangan dalam penelitian ini adalah adanya beberapa siswa yang kurang bersungguh-sungguh menanggapi permasalahan yang diberikan ketika mereka diminta untuk memikirkan permasalahn tersebut. Kemudian kurangnya waktu yang tersedia untuk mendiskusikan permasalahan yang diberikan kepada siswa serta menyampaikan hasil diskusi tersebut di depan kelas. Selain itu saat peneliti memberikan penjelasan materi pembelajaran kepada siswa ada yang tidak memahami pelajaran tetapi malu untuk bertanya sehingga pada saat diskusi siswa tersebut mendiskusikan hal-hal yang tidak berkaitan tentang materi pembelajaran sehingga berdampak pada hasil belajarnya. Adapun kelebihan penelitian ini adalah sebagian besar siswa lebih aktif bertanya maupun mengeluarkan pendapat dan ide-ide kreatifnya dalam menyelesaikan masalah.
Pembelajaran pada kelas yang diawali dengan pemberian masalah yang konstektual diharapkan akan merangsang siswa berpikir aktif membangun pemahaman dan ide-ide untuk menemukan penyelesaian dari masalah (solusi). Masalah konstektual dapat memuat pengetahuan yang mudah dan dapat dibayangkan oleh anak. Hal ini sejalan dengan teori Piaget yang berkembang menjadi teori konstruktivisme mengatakan bahwa pengalaman-pengalaman fisik dan manipulasi lingkungan penting bagi proses dimana anak secara aktif membangun sistem makna dan pemahaman realitas melalui pengalaman-pengalaman dan interaksi mereka. Dalam proses pembelajaran diharapkan siswa mampu menghubungkan konsep-konsep matematika yang telah dipelajari dengan permasalahan kehidupan sehari-hari dan mampu menyelesaikannya dengan beragam cara, meningkatkan kemampuan pemecahan masalah matematika siswa sehingga tujuan pembelajaran dapat tercapai serta mempertanggungjawabkan apa saja yang ia peroleh. Harahap dan Surya (2017) menyatakan bahwa melatih siswa dengan pemecahan masalah dalam pembelajaran matematika bukan hanya sekedar mengharapkan siswa dapat menyelesaikan soal atau masalah yang diberikan, namun diharapkan kebiasaaan dalam melakukan proses pemecahan masalah membuatnya mampu menjalani hidup yang penuh kompleksitas permasalahan. Surya (2009) menyatakan pembelajaran kooperatif dengan berbasis masalah dapat memecahkan masalah matematika dan kehidupan sehari-hari.

Adapun kelemahan yang timbul dalam proses pembelajaran tipe TAI adalah kurangnya waktu yang dibutuhkan dalam memecahkan masalah, masih banyak siswa yang kekurangan waktu dalam memecahkan masalah begitu juga saat guru mengalami kesulitan menangani siswa

Septya Giartianti, E.Elvis Napitupulu. Perbedaan Kemampuan Pemecahan Masalah Matematis Siswa Melalui Pembelajaran Kooperatif Tipe Team-Assisted Individualization dan Numbered Head Together. Jurnal Inspiratif, Vol. 4, No. 1 April 2018. 
pada proses pembelajaran individual karena waktu yang tidak cukup. Sedangkan pada pembelajaran NHT banyak siswa yang kurang aktif dalam mengikuti diskusi dan hanya menunggu jawaban yang diberikan teman.

Walaupun demikian, baik Team Assysted Individualization maupun Numbered Head Together ternyata dapat meningkatkan kemampuan pemecahan masalah matematik di kedua kelas tersebut pada materi aritmatika sosial.

\section{KESIMPULAN DAN SARAN}

Berdasarkan analisis data dan pembahasan maka terdapat kesimpulan dalam penelitian ini sebagai berikut:

Terdapat perbedaan kemampuan pemecahan masalah matematika siswa yang belajar dengan menggunakan model pembelajaran kooperatif tipe TAI dan pembelajaran kooperatif tipe NHT pada materi aritmatika sosial di kelas VII SMP Negeri 3 Pulau Rakyat.

Berdasarkan hasil penelitian ini, saran yang dapat diajukan peneliti adalah:

1. Kepada Guru

a. Dalam setiap pembelajaran sebaiknya menciptakan suasana belajar yang member kesempatan kepada siswa untuk mengembangkan kemampuan pemecahan masalah sehingga menciptakan susasana belajar yang lebih aktif.

b. Hendaknya lebih banyak melatih siswa dalam indikator pemecahan masalah yakni merencanakan penyelesaian masalah karena dilihat dari hasil postest kemampuan pemecahan masalah matematik yang dilakukan di kelas eksperimen A dan B diperoleh bahwa siswa masih mengalami kesulitan saat kedua tahap tersebut. Diharapkan dengan latihan-latihan soal yang diberikan oleh guru, kemampuan pemecahan masalah matematik siswa semakin baik kedepannya terutama dalam indikator merencanakan penyelesaian masalah.

2. Kepada Peneliti Lanjutan Hasil penelitian ini dapat dijadikan pertimbangan untuk menggunakan model TAI pada materi aritmatika social atau materi ajar lainnya dan memberikan pengarahan terlebih dahulu sebelum pelajaran dimulai kepada setiap kelompok untuk saling berdiskusi, mengeluarkan pendapat, tukar pikiran serta menyatukan pikiran-pikiran atau ide setiap anggota kelompok untuk menyelesaikan tugas yang diberikan guru.

\section{DAFTAR PUSTAKA}

Abdurrahman, M., (2012), Pendidikan Bagi Anak Berkesulitan Belajar, Rineka Cipta, Jakarta.

Arikunto, S., (2009), Manajemen Penelitian, Rineka Cipta, Jakarta.

Farnika, N., Ikhsan, M., dan Sofyan, H., (2015), Peningkatan Kemampuan Pemahahaman dan Pemecahan Masalah Matematis Siswa Sekolah Menengah Atas Dengan Model Pembelajaran Kooperatif Tipe Team Assisted Individualization, Jurnal Elemen, Vol.1, No.2, hal:144-152.

Harahap, E. R. dan Surya, E. 2017. Kemampuan Pemecahan Masalah Matematis Siswa Kelas VII dalam Menyelesaikan Persamaan Linear Satu Variabel, Edumatica, 7(1), 44-54.

Hudojo, H., (2015), Pengembangan Kurikulum dan Pembelajaran Matematika, Universitas Negeri Malang, Malang.

Istarani, (2012), 58 Model Pembelaran Inovatif, Media Persada, Medan.

Septya Giartianti, E.Elvis Napitupulu. Perbedaan Kemampuan Pemecahan Masalah Matematis Siswa Melalui Pembelajaran Kooperatif Tipe Team-Assisted Individualization dan Numbered Head Together. Jurnal Inspiratif, Vol. 4, No. 1 April 2018. 
Novriani, M. R. and Surya, E. 2017. Analysis of Student Difficulties in Mathematics Problem-Solving Ability at MTs SWASTA IRA Medan. International Journal of Science Basic and Applied Research (IJSBAR), 33(3), 63-75.

Rosli, R., Dianne. G., dan Mary, M.C., $\mathrm{P}(2013)$. Assesing Students Mathematical Problem Solving and Problem-Posing Skills, Asian Social Science, Vol.9, No.16. ISSN: 1911-2017. E-ISSN: 19112025.

Rusman, (2014), Model-Model Pembelajaran (Mengembangkan Profesionalisme Guru), Raja Grafindo Persada, Jakarta.

Slavin, R.E., (2005), Cooperative Learning Teori, Riset dan Praktik, Nusa Media, Bandung.

Sumiati, dan Asra, (2013), Metode Pembelajaran, CV Wacana Prima , Bandung.

Surya, E. 2009. Pembelajaran Kooperatif dengan Pendekatan Berbasis Masalah dalam Pemecahan Masalah Matematika. Jurnal Pendidikan Matematika dan Sains, 4 (1), 14-17.

Surya, E., dan Rahayu, R., (2014), Peningkatan Kemampuan Komunikasi dan Pemecahan Masalah Matematis Siswa SMP AR-Rahman Percut Melalui Pembelajaran Kooperatif Tipe Students Teams Achievement Division (STAD), Jurnal Pendidikan Matematika Paradikma, Vol. 7, No. 1, Hal: 24-34.

Septya Giartianti, E.Elvis Napitupulu. Perbedaan Kemampuan Pemecahan Masalah Matematis Siswa Melalui Pembelajaran Kooperatif Tipe Team-Assisted Individualization dan Numbered Head Together. Jurnal Inspiratif, Vol. 4, No. 1 April 2018. 